\section{\&etin \& ELTTaM CONFERENCE}

Malang, Indonesia

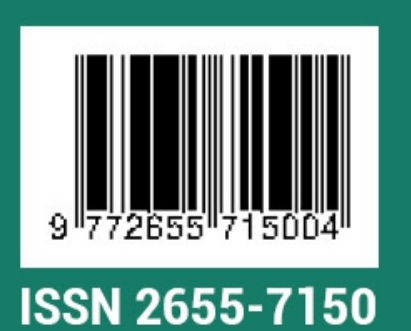

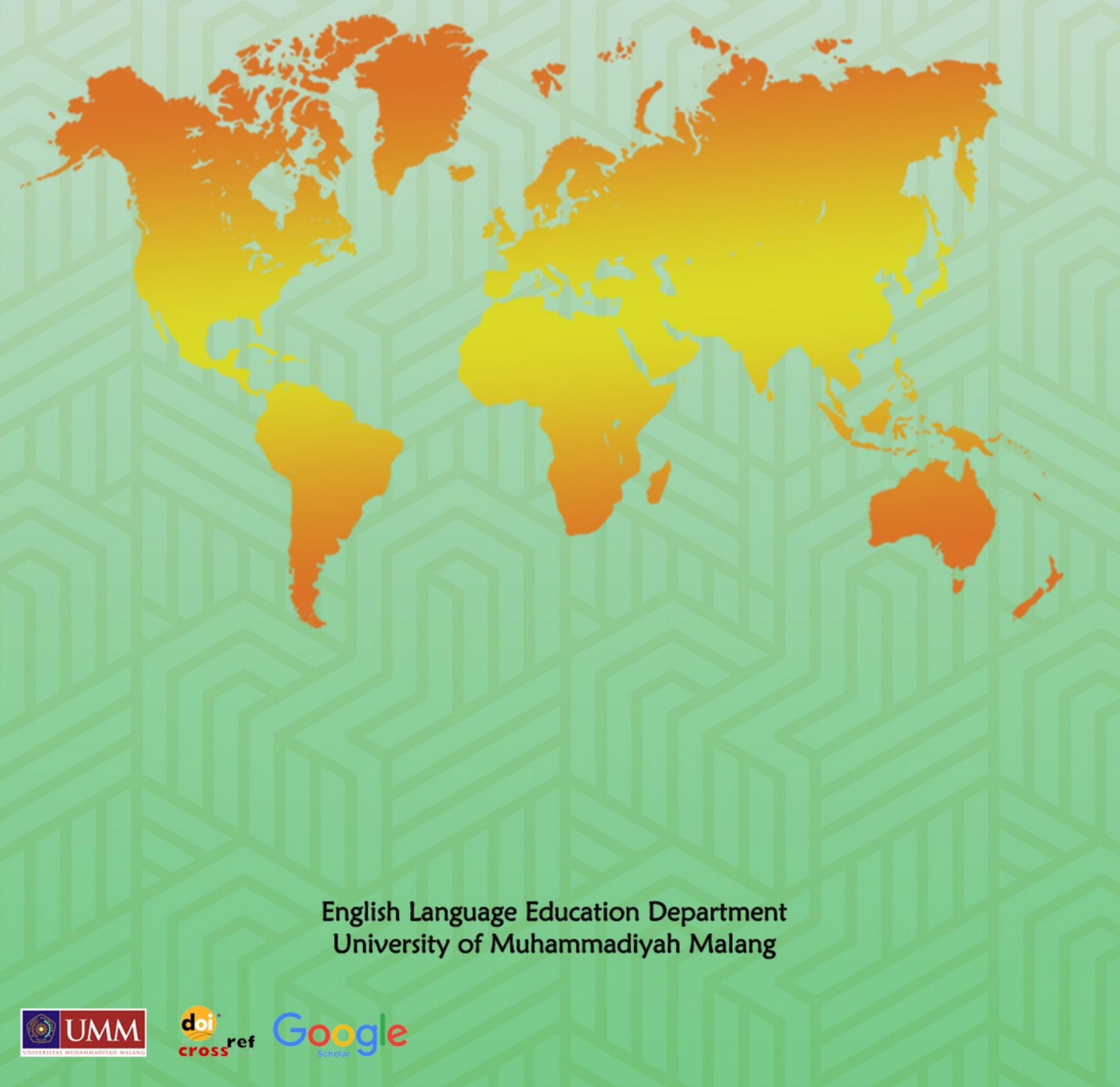




\section{Daftar Isi}

Daftar Isi - i

Critical Literacy and Meaningful Language Learning: A Reflective Study in Academic Debate Class

Oleh: Sueb, Lina Purwaning Hartanti

Linguistic Feature Proximity for Acquiring English Pronunciation among Indonesian EFL Learners: Arabic as the Bridge

Oleh: Riski Lestiono, Rosalin Ismayoeng Gusdian

Technology Use in 'No Private Devices' Boarding Junior High School

Oleh : Diah Fakhmawati 10

An Analysis of Student's Ability in Using Past Tense in Writing Narrative Text

Oleh : Muhamad Azizul Chakim, Haris Dibdyaningsih 16

Students' Need or Stakeholders Need? A Survey Study on the Development of Syllabus in Translation Class

Oleh : Rizky Lutviana, Siti Mafulah, Sugeng Hariyanto, Faisal Rahutomo 18

Improving the Students' Speaking Skill Using Flipped Classroom Strategy through Students' Minimovie Project

Oleh : Dian Maya Kurnia, Reky Lidyawaty

The Investigation into Primacy Effect on Student's Vocabulary Memorization

Oleh : Delli Sabudu

Character-Based Materials Development for Kindergarten Students

Oleh : Iin Inawati

Integrating Multiliteracies Skills through Station Rotation in ESP Reading Program

Oleh : Herlin Afiyanti

Digital Storytelling for Promoting Autonomous Learning Model

Oleh: Rochmatika Nur Anisa

Need Analysis in learning English for Chemical for Industry Students at SMKN 5 Surabaya

Oleh: Rizka Safriyani

Utilizing Audio Recording Feature in PowerPoint to Help EFL Teachers Develop Teaching Materials

Oleh: Dini Kurnia Irmawati, Novita Rosyida, Debri Haryndia Putri, Dian Novita Dewi, Tri Mega Asri 
A Study of Role Play with Comic Strips Implementation in Improving the EFL Students' English Communicative Competence

Oleh: Anja Arowana E.L

Laugh and Learn: Improve Comedy as a Learning Tool for Speaking Class

Oleh: Ary Rahmad Wijaya

Fostering Emergent Learning in Technology - Enhanced Extensive Listening and Viewing Programs

Oleh: Fransisca Maria Ivone

The Extents and Constraints of Video: Colleagues Insights on Instructional Video Implementation in Teaching Speaking

Oleh: Sri Fatmaning Hartatik

English for Specific Purposes: Materials Designing for Dokar Driver in Kuta and Denpasar, Bali

Oleh: Luh Eka Susanti

Error of Omission in QQ Online Chatting: A Study on Chinese ESL Learners at University of Muhammadiyah Malang

Oleh: Desi Rohayati, Erlyna Abidasari

Improving the EFL College Learners' Reading Comprehension through Skimming Technique

Oleh: Mahmud Miftakhul Huda, Rasyidah Nur Aisyah

The Role of ICT Integration in Teaching and Learning English for EFL Students

Oleh: Retma Sari

The Role of Lexical Knowledge and Processing Skills in L2 Reading Outcomes: A Trade-off between Accuracy and Processing Skill Development

Oleh: Sahiruddin

Students Perceptions towards the Implementation of Google Classroom as Media

Oleh: Rizha Galih Faturrochman

The Use of Wordfast as Translation Tool in Translation Class

Oleh: Trisno Tunggal Rahayu Wilujeng, Siti Mafulah

Application of Problem Based Learning and Cooperative Based Learning to Improve Environmental Analysis Ability for Students

Oleh: Yulist Rima Fiandari

Students' Perceptions towards English Learning Materials and Classroom Activities: A Survey of Senior High School Students in Samarinda

Oleh: Weningtyas Parama Iswari, Noor Rachmawaty 
Exploring Teacher Beliefs and Classroom Practice of Teaching EFL Writing in Higher Education

Oleh: Amelia Dwi Imanda

Anxiety on Speaking Class Encountered by Students of English Education Deartment, University of Muhammadiyah Malang

Oleh: Jarum

Combining Games with Buzz Groups in Grammar Class

Oleh: Dwi Taurina, Mila Wardhani

The Use of Picture Media "Public Figure" to Improve Writing Skills on Descriptive Text for Students of Class VII-I SMP Negeri 01 Batu

Oleh : Desy Indriyani

The Correlation between Students' Perceptions on Teacher Feedback and Writing SelfEfficacy

Oleh: Aridah, Agustina Firdhayanti 144

Assessing Student Learning with Five Formative Assessment Activities

Oleh : Dwi Wahyuningtyas

CLIL in Indonesia: The 4C's Framework of Adopted CLIL Approach in Elementary School

Oleh : Khoiriyah 154

A Study on Foreign Language Writing Anxiety at The Third Semester of English Language Education Department in University of Muhammadiyah Malang

Oleh : Sulastri 161

Vocabulary Development of EFL Undergraduates A Cross-sectional Study

Oleh : Kusumarasdyati; Farah Ramadhani 166

Comparing English Vocabulary Level if D-III Culinary Management Class A and Class F Students of Bali International Institute of Tourism

Oleh : I Wayan Suadnyana; Denok Lestari 169

Improving Students' Level of Tolerance by Using Multicutural Based Learning in IKIP Budi Utomo Malang

Oleh: Munawwir Hadiwijaya

Improving Students' Creativity through Project-Based Learning at a Junior High

School Level in Rural Area of Yogyakarta

Oleh: Yulia Nuzulul Hidayah, Ashadi 179

Teaching Science Using English Done by Primary School Teachers in Malang

Oleh: Pritha Anggiarima 
Teacher's Role in Promoting Classroom Language Interaction on Mix-Ability Students at Al-Islam Islamic Boarding School Nganjuk English workplace needs for Professional Engineers: The Contributing to the ESP Program in University

Oleh: Farizal Khusnul Khotimah 189

Learning's Enthusiasm through Brainstorming at Vocational High School

Oleh: Hilda Suat, Nisrina Balqis Huwaida

Students' Perspectives on the Use of Full English in English Learning Classroom

Oleh: Nisrina Balqis Huwaida, Hilda Suat 196

The Implementation of Snake and Ladder Board Game in Teaching Simple Present dan Past Tense

Oleh: Achmad Anang Darmawan, Faishol Hadi 199

Modifying the Traditional Ganes into English Instructional Media to Enhance English Communication

Oleh: Zaenal Abidin

Critical Reflective Teaching of Pre-service English Teachers at UIN Sunan Ampel Surabaya

Oleh: Rakhmawati

The Indonesian EFL Leraners' Attitudes toward Their Own English Accent

Oleh: Alimin Adi Waloyo

Dominant Teacher in Using English as a Medium of Instruction in the Learning Process at SMK Muhammadiyah 1 Batu

Oleh: Ahlan

Enhancing University Students' Higher Order Thinking through Mini Conference Class Based Learning

Oleh: Gusti Milla Quaidy, Afdhol Auliya

English workplace needs for Professional Engineers: The Contributing to the ESP Program in University

Oleh: Lailatul Rifah, Muchtar

Nationalism Perception on Europe Language in Foreign Language Course

Oleh: Sri Hartiningsih

Comic Books as an Aid to Learn English and Foster Noble Characters

Oleh: Mirjam Anugerahwati

English Teachers' Perception on The Implementation of Character Education in Curriculum 2013

Oleh: Heni Puji Lestari, Bambang Widi Pratolo 
English Learning Community in Pare Kediri Indonesia:Its Social Emergence and School Community Partnership

Oleh: Uning Musthofiyah, Elfrida Silalahi

The Word Terror Used in Selected Online Media Headlines: Farming Analysis

Oleh: Rafika Rabba Farah

Should We Move Our Classed to "McD"? The Impacts of Learning Environment and Culture on Learning Process and Behaviour

Oleh: Adi Suryani 265

General Attributes and Learning-teaching Content of Seventh-grade English Textbook "When English Rings a Bell"

Oleh: Kurniawati Nur Fadhilah 272

The Impacts Of Teacher's Direct And Indirect Feedback On The Students' Motivation In Intermediate Grammar At The Second Semester Students Of English Language Education Department Umm

Oleh: Thathit Manon Andini, Erly Wahyuni, and Santi Prastiyowati 282 


\title{
An Analysis of Student's Ability in Using Past Tense in Writing Narrative Text
}

Muhamad Azizul Chakim ${ }^{1}$, Haris Dibdyaningsih, M.Pd ${ }^{2}$

English Student Department, STKIP Al Hikmah - INDONESIA ${ }^{1}$;

English Teacher Department, STKIP Al Hikmah - INDONESIA ${ }^{2}$;

azizchakim17@gmail.com ${ }^{1}$, harisdibdyaningsih@gmail.com²

\begin{abstract}
This research aimed to know the student's ability in using past tense in writing narrative text. The subjects of this research are thirty students of class VIII in SMP Al Hikmah Surabaya. This research used a descriptive quantitative research. In collecting the data, the researcher used document and interview as data collection technique to know student's ability in using past tense in writing narrative text and to get information about student's difficulties in using past tense in writing narrative text. The result of this research showed that $85 \%$ the students were consistent in using past tense in writing narrative text and $15 \%$ the students were inconsistent in using proper past form in writing narrative text. The problem of student's ability in using past tense in writing narrative text were the students lack in vocabulary, the students were inconsistent in using past form and the students were over generalization.
\end{abstract}

\section{Keywords}

Simple Past Tense, Writing, Narrative Text

\section{Introduction}

Mastering writing narrative text is one of skills that Junior High School students have studied. In writing narrative text, the students should know how to write well. It usually uses simple past tense. It means the students should know how to use of simple past tense and then, be able to produce a good narrative text. Simple past tense is an activity that happen in the past or situation that began and ended in the past.

Writing narrative text is one of kinds of text that the students felt difficulties in writing because of several reasons. First, the students argued that they lack vocabulary, it makes the students to develop the idea by using simple past tense in writing narrative text. Second, this is the big problem because the students still inconsistent in using past tense in writing narrative text.

However, simple past should be learned by the students at Junior High School. The problem that is face by the students is important to be analysed. Therefore, the researcher interests to conduct a research about student's ability in using simple past. Simple past in narrative text is one of the elements in language features which becomes the characteristics of narrative text.

According to Azar (1992:25), simple past is used to talk about activities or situations that began and ended in the past. Simple past tense is used for events or situation that exist last year, yesterday, last week, two days ago, etc. There are two kinds of verb : regular and irregular verbs. For example : regular : stayed, arrived, walked, etc. Irregular : ate, took, slept, etc. It means that simple past talk about activities that happen in the past, it used regular and irregular verb.

Nunan (2003:88), writing is the work of inventing ideas, thinking about how to express them, and organizing them into statements and paragraphs that will be clear to a reader. It means that to express the ideas by writers in writing, the writers need to organize into statement, that statement or paragraph it makes to easier understand and interest to read by a reader.
Narratives are stories about person or a group of people overcoming problems (Joyce \& Feez, 2000, p. 24). They also explain that narratives show how people react to experiences, explore social and cultural values and entertain the audience. It aims to entertain, to get and retain the attention of the reader or listener of the story (Derewianka, 1990; Joyce \& Feez, 2000; Anderson \& Anderson, 2003; Gerot \& Wignell, 1994).

Based on this research, the students should have the ability in writing narrative text by using past tense. In fact, based on the pre-observation in teaching English at SMP Al Hikmah Surabaya, not at all the students can write narrative text well. Some of the students were difficult to write sentence in using past tense. It was supported by student's score in which is not achieved the standard minimum criteria (KKM) of writing. the students got a difficulties in writing narrative text because they were inconsistent in using past tense in writing narrative text. the researcher wants to know (1) how is student's ability in using past tense in writing narrative text. (2) why the students get a difficulties in writing narrative text. Therefore, the researcher interest to conduct a research about student's ability in using past tense in writing narrative text.

\section{Methodology}

In this research, the researcher conducts this study as descriptive quantitative research, how the student's ability in using past tense in writing narrative text because the research would find out the data at the field based on the fact. According to (Subana and Sudrajat, 2005) descriptive quantitative research achieves fact, situation, variable, and phenomenon that happen at the present in existence. Moreover, the subject of this research were thirty students of class VIII in SMP Al Hikmah Surabaya.

In collecting data, this researcher used document and interview as the data collection technique to know student's ability in using past tense in writing narrative text and to get information about student's difficulties in using past tense in writing narrative text.

For the procedure of this research is. Firstly, after planning what research that researcher wants and then he arranged the subject that appropriate for this research. Secondly, the resercher asked permission to the teacher directly, does she allow or not to conduct a research there. Because this 
research were interviewed and asked the document writing narrative text only. They used to get information of student's ability in using past tense in writing narrative text. Thirdly, the researcher analyzed the student's ability in using past tense in writing narrative text.

The researcher gives an interview to the teacher about the student's ability in writing especially writing narrative text. The researcher prepared the arranging of question to get any information deeply.

\section{Finding and Discussion}

The findings of this study indicate that $85 \%$ of the students were consistent in using past tense in writing narrative text, and $15 \%$ of the students that still inconsistent in using past tense in writing narrative text. in was supported by the fact that there were $26(85 \%)$ students who had good score and all of them consistent in using past tense in writing narrative text. And there were 4 (15\%) students who had good enough score and most of them still inconsistent in using past tense in writing narrative text. Based on this research, the biggest problem is the students that still inconsistent in using past tense in narrative text. When they were writing narrative text, they only focus exploring their mind in writing narrative. So, they forgot in using past tense in writing narrative text Moreover, after doing the research in the field and analyzing the collected data, the researcher would like to give some discussions for the students and teacher.

Firstly, for the English teacher to brief problems of the students might face in using past tense in narrative text. By showing the result of this research, they have to more careful and also find the solution of student's problem. The teacher should give more practice and exercise to the students in using past tense in writing narrative text in order to help them understanding the important aspect of narrative text. Hence, the teacher as facilitator in teaching learning process have to do maximal effort to make all students understood about the material. When the students felt difficult in using past tense, the teacher can explain the verb base that want to change into past tense. in the other hand, they also have to increase their knowledge as well as their teaching method, so the students will be motivated to write English especially writing narrative text.

Secondly, for the students, it is to learn and practice more in writing English by themselves. They can apply writing in their experience in using past tense everyday also. So, they will get a good writing narrative text. In addition, they also have motivation to improve thier writing English. Therefore, the students have to practice more in writing English to increase their ability in using past tense in writing narrative text.

The researcher analyses the student's ability in using past tense in writing narrative text. Based on the research findings and discussion, the researcher found any mistakes from the student's writing. When they were narrative text, they have fun with writing their imagination and mind. So, they forgot to focus on the language features of narrative text such as using of past tense, using of time sequence, and using of direct speech. However, they explore their mind to write a narrative text, but they not focus or not consistent in using past tense in narrative text. Moreover, they also still lack in vocabulary. So, when they are writing narrative text, they are doing redundant the vocabulary. It will make narrative text confusing.

\section{Conclusion}

The researcher concludes that the students of SMP $\mathrm{Al}$ Hikmah Surabaya class VIII were enough able in using past tense in writing narrative text. Based on the research findings, discussion, and conclusion, it is suggested that the teachers should give more more practice and exercise to the students in using past tense in writing narrative text in order to help the students understanding about the important aspect of narrative text. Moreover, the teachers need to put more effort in teaching since they need more guidance in using past tense in writing narrative text.

6.1 From this research, we can know that most of them consistent in using past tense in writing narrative text. there were $26(85 \%)$ students that consistent in using past tense in writing narrative text. And there were 4 (15\%) students that still inconsistent in using past tense in writing narrative text. So, from this research, researcher offering a suggesstion that the teacher should give more practice the students in using past tense in writing narrative text and more effort to guide the students in writing narrative text.

\section{5. REFERENCES}

Anderson, K., and Anderson, M. (2003). Text Types in English 2. The Modern Art Production Group. Malaysia.

Azar, B., S. and Hagen, S., A. 2003. Basic English Grammar. Third Edition. Pearson Longman.

Derewianka, B. (1990). Exploring How Texts Work. Primary English Teaching Association.

Gerot, L. and Wignell, P. (1994). Making Sense of Functional Grammar. Sydney, NSW: AEE.

Harmer, Jeremy. 2004. How to Teach Writing. Pearson Longman. Edinburgh.

Hyland, K. 2002. Teaching and researching writing. Longman. University of Leeds.

\subsection{Hyland, K. 2003. Second Language Writing.} Cambridge University Press. Cambridge.

Joyce, H., and Feez, S. (2000). Writing Skills: Narrative and Non-Fiction Text Types. Sydney: Phoenix Education Pty Ltd.

Luthfiyati, D., Latief, M, A., and Suharmanto. 2015. Mistakes in Writing Narrative Texts by The Student Senior High School. Journal of Humanities Education, Vol 3, No. 2, 161164.

Mulyaningsih, D, U. 2013. An Analysis of Student's Ability in Writing Narrative Text. Journal of English and Education, 1(2), 16-22.

Nunan, D. 2003. Practical English Langugae Teaching. McGraw-Hill: Harper Collins Publisher.

Subana, M. And Sudrajat. (2005). The Basic of Research Methods. Pustaka Setia. Bandung. 